\title{
Aktualisasi Kerukunan Masyarakat Beda Agama di Kelurahan Pager Kecamatan Rakumpit Kota Palangka Raya
}

\author{
Ajahari $^{\text {a,1 }}$ \\ ${ }^{a}$ Institut Agama Islam Negeri (IAIN) Palangka Raya, Kalimantan Tengah, Indonesia \\ Iajahari@iain-palangkaraya.ac.id
}

ABSTRACT

Article history:

Received : 2018-08-13

Revised : 2018-08-14

Accepted : 2018-08-20

Keywords:

Actualization

Harmony

Different beliefs
This study is aimed at finding out the ways of the different beliefs of people actualizing harmony, factors for people in actualizing the harmony and the role of religious leaders, traditional leaders and the local government in creating harmony in Pager Village. The research used the methods of observation, interviews and documentation. The results reveals that harmony in the Pager Village is well built, and it is original. 1) Actualization of interreligious harmony is realized in the form of inviting and visiting each other during religious celebrations, activities of death, marriage and celebration. 2) The harmony, which is built is based on several factors such as theological factors, factors of philosophical values and local cultural wisdom such as belom bahadat values, hapaka basara, philosophy of Huma Betang teaching the values of harmony and togetherness; emotional factors and patriotic and nationalist values. 3) The creation of harmony and harmonious among residents in the Pager village is inseparable from the involvement of religious leaders, traditional leaders of each religion, the chief of the RT / RW who in their interaction and social behavior set a model to the people.

Copyright (? 2018 IAIN Palangka Raya. All rights reserved.

\section{Pendahuluan}

Di Indonesia, pluralitas beragama diakui sebagai konteks kongkrit dimana agama dihayati oleh pemeluknya. Sebagai orang yang mengakui beragama mesti menerima dan menghayati bahwa pluralitas agama adalah sebagai wujud manifestasi besarnya rahmat Tuhan. Hal ini dapat dibuktikan melalui pesan normatif Tuhan Q.S. [49:12] bahwa pluralitas atau perbedaan agama adalah kehendak Tuhan sebagai sebuah keniscayaan. Tujuan dari kehendak ini tidak lain adalah supaya semua ciptaan-Nya di dunia ini menjadi seimbang baik secara fungsional maupun secara struktural. Artinya, melalui pesan normatif tersebut Tuhan menyatakan bahwa Dia menghargai heterogenitas (perbedaan) dalam berbagai dimensi, baik bahasa, ras, suku, agama, bangsa, maupun adat istiadat (19).

Heterogenitas masyarakat antar agama merupakan sunnatullah bahwa manusia memiliki sikap saling ketergantungan dalam menggali dan mengembangkan potensipotensi agar menjadi masyarakat antar agama yang dinamis. Apabila potensi-potensi masyarakat antar agama ini terbentuk, maka realitas yang diharapkan di masa kini dan mendatang akan terbangun sebuah tatanan masyarakat multikultural. Masyarakat antar agama ini tidak hanya mengakui adanya perbedaan, akan tetapi juga tumbuh sikap saling menghormati dan menghargai secara tulus, komunikatif, terbuka, tidak saling curiga, memberikan tempat terhadap agama dan keyakinan lain serta tradisi, adat dan budaya untuk lebih hidup dan berkembang secara wajar, sehingga tercipta rasa toleransi atas dasar perwujudan rasa kemanusiaan.

Kenyataan historis sosiologis sepanjang perjalanan kehidupan manusia selama ini, konflik, ketegangan dan bahkan kerusuhan berkepanjangan atas nama agama masih sering terjadi. Agama yang mestinya dapat membumi dalam kehidupan antar pemeluknya, oleh penganutnya terkadang tidak dapat dijadikan sebagai institusi 
integritas masyarakat antar umat beragama. Oleh karena itu, kiranya konflik yang mengatas namakan agama perlu dianalisa dalam hubungan politik, ekonomi maupun sosial budayanya. Apabila konflik tersebut murni konflik agama semata, maka masalah kerukunan sejati tetap dibangun atas dasar nilai-nilai keadilan, kebebasan dan hak asasi manusia, yang menyentuh keluhuran martabat manusia. Semakin dalam rasa keagamaan, maka semakin dalam pula rasa keadilan dan kemanusiaannya (2).

Penyebab timbulnya kerawanan hubungan bahkan kerusuhan antar umat beragama bersumber dari berbagai aspek antara lain: sifat dari masing-masing agama yang mengemban tugas dakwah/misi seperti Islam, Kristen dan Buddha, kurangnya pengetahuan para pemeluk agama terhadap agamanya sendiri dan pihak lain, kaburnya batas antara sikap memegang teguh keyakinan agama dan toleransi dalam kehidupan masyarakat, kecurigaan masing-masing pihak akan kejujuran pihak lain baik intern umat beragama, antar umat beragama, maupun antar umat beragama dengan pemerintah. Selain itu adanya perbedaan yang cukup mencolok dalam status sosial, ekonomi dan pendidikan antar berbagai golongan agama, kurangnya komunikasi antar pemimpin masing-masing umat beragama dan adanya kecenderungan fanatisme yang berlebihan antar umat beragama sehingga mendorong munculnya sikap kurang menghormati bahkan memandang rendah pihak lain (11).

Kaitannya dengan aktualisasi kerukunan hidup umat beragama di Kelurahan Pager Kecamatan Rakumpit merupakan sesuatu hal yang menarik untuk diteliti secara serius, ilmiah dan mendalam. Hal ini disebabkan dari jumlah penduduk yang ada di Kelurahan Pager Kecamatan Rakumpit Kota Palangka Raya yang berjumlah kurang lebih 643 jiwa merupakan masyarakat yang hiterogen dari sisi agama yakni Islam, Krsiten, Hindu Kaharingan. Sisi lain informasi awal yang didapat penulis mengenai hubungan antar agama dalam kehidupan sosial keagamaan adalah keharmonisan, saling mengunjungi dan membantu dalam berbagai hal. Bahkan ada beberapa keluarga yang berbeda agama hidup dalam satu rumah. Kehidupan keberagamaan antar umat beragama seperti yang ditampilkan warga Kelurahan Pager
Kecamatan Rakumpit ini memunculkan berbagai macam pertanyaan seperti bagaimana warga Kelurahan Pager Kecamatan Rakumpit mengaktualisasi kerukunan hidup beragama dalam kehidupan keseharian mereka, apa yang mendasari kerukunan yang ditampilkan warga Kelurahan Pager Kecamatan Rakumpit, dan bagimana peran yang dimainkan oleh tokoh agama/adat membangun harmonisasi dan kerukunan antar masyarakat berbeda agama serta seberapa besar dampak kerukunan yang sudah dibangun selama ini memberikan kontribusi untuk menciptakan kedamaian (serenities) dan keharmonisan dalam masyarakat.

Sejauh pengetahuan penulis penelitian tentang Aktualisasi Kerukunan Hidup Umat Beragama belum banyak dilakukan kecuali yang berkaitan dengan interaksi sosialnya, dan kebanyakan peneliti bertolak pada suatu pandangan bahwa perbedaan agama atau keyakinan akan mempengaruhi hubungan sosial di antara masyarakat. Seperti penelitian yang dilakukan oleh Toto Suryana mengenai konsep dan aktualisasi kerukunan antar umat beragama. Dalam kesimpulannya dijelaskan bahwa keberagaman merupakan ketentuan dan realita dari Tuhan Yang Maha Esa, perbedaan yang terjadi merupakan fakta yang harus disikapi secara positif sehingga akan terjalin hubungan kemanusiaan yang saling menghargai dan menghormati antar umat agama (17). Selanjutnya penelitian yang dilakukan oleh Hakis mengkaji tentang komunikasi antar umat beragama di kota Ambon. Hasil kajiannya menunjukkan bahwa untuk menciptakan kerukunan antar umat beragama diperlukan langkah-langkah seperti menjalin komunikasi yang damai dengan semua golongan masyarakat, memberikan pendidikan multikulturalisme dan membuka ruang publik serta memperhatikan manajemen perdamaian itu sendiri (3).

Penelitian ini memiliki beberapa tujuan yaitu; Pertama, untuk mengetahui dan mendeskripsikan cara masyarakat beda agama mengaktualisasi kerukunan umat beragama. Kedua, untuk mengetahui faktor atau landasan aktualisasi kerukunan pada masyarakat beda agama. Ketiga, untuk mengetahui keterlibatan tokoh agama, tokoh adat dan tokoh masyarakat dalam menciptakan kerukunan pada masyarakat 
beda agama di Kelurahan Pager Kecamatan Rakumpit Kota Palangka Raya. Hasil penelitian ini nantinya diharapkan dapat berguna untuk memberikan informasi kualitatif mengenai kerukunan dan aspek interaksi sosial antar masyarakat beda agama sehingga dapat digunakan oleh pihak-pihak pengambil kebijakan serta pihak-pihak yang berkepentingan dalam merumuskan model kerukunan dan pembinaan kehidupan beragama dan dakwah pada masyarakat yang plural. Kemudian dari sudut pandang ilmu sosial penelitian ini diharapkan juga dapat berguna untuk memperkaya empirik yang aktual mengenai landasan teoritis, bentuk, dan faktor pendukung serta aspek yang berpeluang dapat menimbulkan kecemasan sosial, peran dan kontribusi tokoh agama serta pemuka adat terhadap terciptanya kerukunan di Kota Palangka Raya baik sebagai data banding maupun sebagai informasi tambahan dari kegiatan penelitian yang sejenis.

\section{Metode Penelitian}

Penelitian ini merupakan penelitian lapangan (field research) yang bersifat kualitatif dan emik, dalam arti bahwa peneliti mengumpulkan data berupa cerita-cerita dari subyek dan diungkapkan apa adanya sesuai dengan bahasa dan pandangan subyek (4). Pendekatan yang digunakan dalam penelitian ini adalah pendekatan kualitatif deskriptif. Melalui pendekatan ini memungkinkan bagi peneliti langsung mencari dan mengumpulkan data atau masalah yang dipelajari, tanpa harus terikat untuk membuktikan benar atau tidaknya suatu teori yang sudah pernah dikemukakan oleh para ahli.

Penelitian ini berusaha menggali informasi sebanyak mungkin terkait dengan pemahaman, pandangan dan pengalaman subyek penelitian tentang makna kerukunan, aktualisasi kerukunan, faktor pendorong terciptanya kerukunan serta peran yang dimainkan oleh tokoh agama, tokoh adat dan tokoh masyarakat terhadap tercapainya kerukunan masyarakat beda agama di Kelurahan Pager Kecamatan Rakumpit Kota Palangka Raya.

\section{Hasil dan Pembahasan}

a. Aktualisasi Kerukunan Masyarakat Beda Agama di Kelurahan Pager

\section{Kecamatan Rakumpit Kota Palangka Raya}

Untuk merealisasi hidup rukun di tengahtengah masyarakat dalam praktik keseharian tampaknya antara subyek yang satu dengan yang lain, tidak jauh berbeda. Secara umum kerukunan dan harmonisasi baik internal maupun antar pemeluk agama yang berbeda di kelurahan Pager selama ini cukup terjaga dan berjalan dengan baik. Kalaupun terjadi perbedaan pandangan dalam beberapa kasus, namun hal ini mereka anggap sebagai dinamika masyarakat dan wajar terjadi. Perbedaan pandangan tidak sampai menimbulkan gesekan dan berakibat terganggunya keharmonisan antar warga, antar agama, antar suku dan antar budaya yang ada. Menurut keterangan seorang pendeta, toleransi antar agama di Pager terjalin sangat baik, dan keakraban sesama warga terbangun dengan bagus (8).

Berdasarkan hasil observasi dan wawancara terhadap subyek penelitian, maka dapat dideskripsikan bahwa cara masyarakat menunjukkan kerukunan satu sama lain adalah dengan jalan saling mengundang, mengunjungi dan saling membantu. Seperti pada hari-hari besar keagamaan, ketika Idul Fitri warga muslim Pager yang merayakannya mengundang tetangga yang nonmuslim untuk datang dan makan. Demikian sebaliknya ketika Natal pihak nonmuslim juga mengundang tokoh dan warga muslim lainnya untuk berkunjung. Keunikan lain pada masyarakat yang beragama Kristen, sehari sebelum perayaan Natal, bahan perlengkapan dapur seperi beras, ayam atau daging dan perlengkapan dapur lainnya diserahkan kepada salah satu warga muslim untuk dimasak dan dimakan secara bersamasama dengan warga muslim lainnya. Menurut subyek yang diwawancarai, tradisi tersebut merupakan salah satu bentuk penghormatan dan penghargaan terhadap saudarasaudaranya yang muslim (6).

Menurut ketua MUI Kecamatan Rakumpit Kota Palangka Raya kegiatan saling mengundang saat ada hari besar keagamaan tidak hanya dilakukan antar warga biasa tetapi juga oleh para tokoh agama dan tokoh adat di daerah ini (15). Kebiasaan saling kunjung mengunjungi pada hari raya keagamaan tanpa melihat perbedaan agama 
dan hubungan kekerabatan. Demikian juga budaya saling membantu saat salah seorang warga lain mengalami musibah seperti kematian, maka warga muslim dan non muslim juga bahu membahu saling membantu hingga selesai penguburan.

Wujud lain dari kerukunan antar umat beragama yang terdapat di Kelurahan Pager adalah saling memberikan kebebasan dalam melaksanakan ibadah. Memperhatikan toleransi antar umat beragama di Kelurahan Pager dalam hal kebebebasan menjalankan ajaran agama tampaknya berjalan sangat baik, antar umat beragama saling memberikan kebebasan kepada masing-masing pemeluk agama untuk melaksanakan ajaran agama sesuai dengan keyakinan. Selama ini menurut beberapa masyarakat yang diwawancarai tidak pernah terjadi intimidasi salah satu pemeluk agama kepada pihak agama lain yang menjalankan ibadah. Bahkan saat pemeluk agama ingin menjalankan ibadah, ada saja warga yang berbeda agama ikut membantu pada acara keagamaan tersebut sebagai pengamanan seperti yang dilakukan $\mathrm{Pa}$ Tarno. Namun ada juga warga muslim yang menegaskan tidak pernah terlibat satu kepanitiaan keagamaan sebagaimana yang diungkap oleh Ibu Jumiati (7).

Mewujudkan kerukunan dan toleransi kepada pemeluk agama lain, masing-masing tokoh agama juga tidak segan mengingatkan warga seagama untuk tetap menjaga toleransi dan menjaga perasaan agama lain, menghindari ujaran kebencian dan provokatif, jangan sampai karena alasan agama, tapi dalam pelaksanaannya justru membuat pemeluk agama lain menjadi terganggu. Salah satu contoh ketika saat membangunkan sahur dibulan Ramadhan, atau tadarus Al-qur'an, maka tokoh agama muslim mengingatkan agar dalam penggunaan pengeras suara keluar untuk membatasi waktu penggunaannya. Demikian juga materi-materi dakwah yang disampaikan agar tidak membuat ketersinggungan pemeluk agama lain.

\section{b. Faktor Pendorong Masyarakat Beda Agama dalam Mengaktualisasi Kerukunan Masyarakat}

Pemahaman dan aktualisasi tentang kerukunan dalam realitas keseharian masyarakat beda agama di kelurahan Pager tidak bisa dilepaskan dari persepsi atau pemaknaan mereka tentang kerukunan, kedalaman pengetahuan, wawasan, pengaturan budaya dan pengalaman serta tingkat relegiusitas pemahaman keagamaan yang dimiliki oleh masyarakat. Dari beberapa masyarakat yang diwawancara, nampaknya secara umum mereka memahami makna dari kerukunan tidak jauh berbeda satu sama lain.

Dari beberapa pernyataan masyarakat yang diwawancarai, tampaknya secara umum dapat disimpulkan bahwa pemaknaan terhadap kerukunan menurut mereka adalah hidup berdampingan secara damai, tanpa membedakan adat istiadat, suku dan agama, saling menghormati dan menghargai, saling memberikan kebebasan masing-masing agama untuk menjalankan ibadah sesuai keyakinannya, terhindar dari konflik, bersatu padu di dalam membangun masyarakat sehingga tercipta ketenangan dan kedamaian dalam masyarakat.

Mengenai hubungannya dengan berbagai macam cara, masyarakat beda agama memili cara tersendiri mengimplementasi kerukunan di tengah-tengah masyarakat, dari wawancara yang dilakukan terhadap 15 orang subyek, terungkap ada beberapa faktor yang melatarbelakangi sekaligus menjadi landasan atau dasar pandangan mereka melakukan berbagai kegiatan sebagaimana disebukan diatas, yakni :

Pertama, nilai dan pemahaman agama masyarakat yang memandang bahwa antara pemeluk agama yang satu dengan agama yang lain tidak berbeda, karena semuanya baik, yang membedakan hanya tata cara beribadah dan tempat ibadahnya saja. Hal ini terungkap dari wawancara dengan seorang Mantir adat Hindu Kaharingan, Manan Muallaf dan Pendeta Kristen.

Kedua, nilai budaya masyarakat setempat. Sebagaimana pemahaman keagamaan, nilai yang lahir dari budaya masyarakat setempat sejak berabad-abad lalu menjadi salah satu daya dorong munculnya sikap rukun dan harmonis ditengah-tengah masyarakat multi agama di kelurahan Pager. Dalam konteks nilai budaya setempat ini, ditemukan nilai budaya yang menjadi daya ikat terjalinnya kerukunan dan keharmonisan dikalangan masyarakat beda agama di Pager seperti Budaya "Belum Bahadat" yang berarti hidup berakhlak, beretika atau beradab. Hapakat 
Basara (permufakatan bersama), filosofi Rumah Betang yang mengajarkan makna hidup harmonis dan kebersamaan.

Ketiga, pandangan terhadap nilai kemanusiaan (humanistik). Pandangan terhadap nilai kemanusiaan yakni pandangan sebagai sama-sama keturunan anak cucu Adam tampaknya juga mewarnai dan menjadi alasan terciptanya kerukunan di kalangan masyarakat Pager. Beberapa masyarakat memandang bahwa sebagai sesama manusia wajib untuk saling tolong menolong satu sama lain tanpa melihat latar belakang budaya dan bahkan agama. Dimensi ukhuwah basyariah (persaudaraan yang diikat oleh nilai-nilai kemanusiaan) menjadi bagian dari pandangan dan prinsip hidup masyarakat.

Keempat, faktor hubungan kekerabatan atau kekeluargaan. Interaksi sosial yang harmonis antar masyarakat beda agama di Pager terjadi juga disebabkan oleh fakor hubungan kekerabatan. Sejumlah penduduk Pager memiliki hubungan kekeluargaan atau kekerabatan antar mereka yang berbeda agama. Hal ini tentu saja menjadi modal dalam rangka unuk mengembangkan hubungan yang lebih mesra ditengah-tengah keluarga bahkan masyarakat secara luas.

Kelima, pandangan tenang nilai kebangsaan dan nasionalisme. Kesadaran akan adanya pluralitas masyarakat Indonesia sangat tampak dalam pandangan beberapa subyek, demikian juga wawasan dan semangat nasionalisme, sebangsa dan setanah air tanpa membedakan suku dan agama memiliki andil dalam menjaga kerukunan dan keutuhan masyarakat. Semangat ini menurut masyarakat sesungguhnya telah diwariskan oleh para pendahulu bangsa ketika memperjuangkan kemerdekaan Indonesia dan semangat yang telah diwariskan para pendiri negara ini harus ada disetiap hati masyarakat jika menginginkan masyarakat dalam keadaan damai dan aman.

Pandangan masyarakat bahwa kebebasan menjalankan ajaran agama dan budaya merupakan hak asasi yang dilindungi oleh Undang-Undang, oleh karena itu setiap pemeluk agama hendaknya menyadari hal ini. Sebagai makhluk sosial, manusia membutuhkan bantuan orang lain dalam memenuhi kebutuhan hidupnya, baik kebutuhan material maupun spiritual Setiap warga masyarakat juga punya hak untuk hidup di seluruh wilayah Indonesia dari Sabang sampai Marauke.

\section{c. Peran Pemerintah, Tokoh Agama, Tokoh Adat dalam Menciptakan Kerukunan Masyarakat Beda Agama di Kelurahan Pager}

Kerukunan antar umat beragama tidaklah tercipta dengan sendirinya, akan tetapi selalu terkait dengan berbagai peran yang dimainkan baik oleh pemerintah, tokoh agama, tokoh adat, tokoh pemuda dan bahkan peran wanita juga tidak dapat diabaikan. Tugas untuk mewujudkan kerukunan antar umat beragama merupakan tugas bersama seluruh golongan masyarakat dan pemerintah. Karena setiap individu dan kelompok umat beragama setiap harinya saling berinteraksi satu sama lain dalam berbagai keperluan, maka diperlukan pemahaman secara benar dan tepat mengenai arti kerukunan antar umat beragama bagi kepentingan mareka (13).

Berdasarkan observasi dan hasil wawancara dengan beberapa masyarakat, keterlibatan elit agama, tokoh adat, tokoh pemuda dan pemerintah terhadap terciptanya kerukunan di kelurahan Pager di dapat data bahwa keterlibatan dan peran tokoh agama setempat baik dari muslim seperti ketua MUI kecamatan, Pendeta dari Kristen dan Mantir Kepala Adat, ketua RT dalam perspektif subyek penelitian dirasakan cukup baik. Peran tersebut tampak pada keterlibatan mereka pada berbagai kegiatan keagamaan dan kemasyarakatan baik secara formal maupun informal. Keterlibatan tokoh-tokoh merupakan media yang dinilai cukup memberikan andil terciptanya kerukunan dan keharmonisan antar warga masyarakat beda agama di kelurahan Pager. Demikian juga peran tokoh pemuda dan peran wanita yang dipandang sebagai tokoh dan pimpinan organisasi sosial kemasyarakatan seperti PKK, Ketua Yasinan/Ketua Arisan diakui baik secara langsung maupun tidak langsung berkontribusi dalam memperkokoh hubungan antar para anggotanya di kelurahan Pager.

Wujud nyata potret keterlibatan mereka yang disebutkan diatas adalah dengan memberikan pencerahan, sebagai mediator jika terjadi disharmoni dalam masyarakat dan saling mengingatkan akan pentingnya membangun kerukunan dan menjaga 
kebersamaan antar warga pada kegiatan sosial keagamaan dan kemasyarakatan, memfasilitasi jika terjadi gesekan antar warga baik seagama maupun antar agama, memberikan contoh dalam menjaga kebersamaan dengan saling mengundang pada saat hari raya keagamaan, perkawinan dan jika terjadi musibah bahkan saling memberikan bantuan satu sama lain. Mereka juga saling bahu membahu dan membantu serta bekerjasama dalam berbagai kegiatan sosial seperti gotong royong, demikian juga peran yang dimainkan ibu-ibu sebagai ketua perkumpulan dalam masyarakat dalam mengorganisir anggotanya yang berasal dari latar agama yang berbeda dalam mencapai tujuan perkumpulan bagian yang tidak dapat dilepaskan dari upaya membangun kerukunan di kelurahan Pager.

Ketokohan, figur serta teladan yang ditunjukkan oleh tokoh agama dan tokoh adat didalam menjaga keharmonisan dan kebersamaan di Pager seolah menjadi magnet yang mampu merekatkan dan mendekatkan antar warga beda agama di kelurahan ini. Berdasarkan hasil wawancara dan observasi aktualisasi kerukunan yang tercipta dalam masyarakat Pager kecamaan Rakumpit Palangka Raya diwujudkan melalui berbagai macam cara seperti melalui saling mengunjungi saat hari raya keagamaan, saling memberikan hadiah, pemberian kebebasan dalam melaksanakan ajaran agama, gotong royong dan kerja sosial, pemberian daging sapi kurban dan bahkan ikut terlibat dalam beberapa acara keagamaan khususnya keagamaan muslim.

Kebudayaan yang ditampilkan masyarakat beda agama sebagai wujud dari kerukunan diantara mereka tampaknya sejalan dengan teori sruktural fungsional. Dalam perspektif teori ini apa yang ditampilkan oleh warga beda agama di kelurahan Pager dalam kaitan dengan bentuk-bentuk prilaku yang menunjukan kerukunan dan keharmonisan, karena pada dasarnya semua warga terutama dalam perspektif subyek penelitian memandang bahwa keteraturan, ketertiban dan keharmonisan serta kerukunan merupakan sebuah kebutuhan mendasar, sehingga masyarakat dipadang sebagai suatu sistem sosial yang saling berkaitan dan membutuhkan serta menyatu dalam keseimbangan.
Menurut perspektif teori fungsionalisme struktural bahwa masyarakat pada dasarnya terintegrasi berdasarkan kata sepakat anggotanya terhadap nilai-nilai kemasyarakatan tertentu. Mereka mempunyai suatu kesepakatan umum (general agreement) yang memiliki daya mengatasi perbedaanperbedaan pendapat dan kepentingan di antara para anggotanya. Teori ini memandang masyarakat sebagai suatu sistem yang secara fungsional terintegrasi ke dalam suatu bentuk keseimbangan (12). Teori ini juga melihat masyarakat sebagai sistem sosial secara keseluruhan menciptakan kelakuan-kelakuan yang terdiri dari norma-norma yang dianggap sah dan mengikat oleh anggotanya menjadi pengambil bagian (partisipasi) dari sistem itu. Keseluruhan dari institusi-institusi yang menentukan sistem sosial itu sedemikian rupa saling menguntungkan dengan semua bagian lain sehingga perubahan dalam suatu bagian mempengaruhi yang lain dan keadaan sistem secara keseluruhan (5).

Jika dilihat dari perspektif teori struktural fungsional diatas, maka dalam sistem sosial agama dipandang mempunyai peran dalam menciptakan ikatan bersama baik di antara anggota-anggota beberapa masyarakat maupun dalam kewajiban-kewajiban sosial yang membantu mempersatukan masyarakat tersebut (14). Teori struktur fungsional juga memandang bahwa: Pertama, Masyarakat merupakan suatu perpaduan nilai-nilai budaya bersama yang dilembagakan menjadi normanorma sosial dan dimantapkan oleh individuindividu kepada semua motivasi. Karena itu, perilaku sosial individu sesungguhnya di dorong dari nilai intrinsik (dalam batin) oleh tujuan-tujuan bersama dengan orang lain, dimana diharapkan semua struktur lembaga sosial dalam sebuah sistem dapat berjalan sesuai dengan fungsinya secara sadar. Kedua, realitas sosial merupakan relasi-relasi yang membentuk sistem sosial yang mempunyai dua ciri khas. Ciri pertama, konsep fungsi yang dimengerti sebagai sumbangan kepada keselamatan dan ketahanan. Ciri kedua, adanya konsep pemeliharaan keseimbangan sebagai ciri utama dari tiap-tiap sistem sosial. Ketiga, masyarakat adalah suatu sistem yang secara keseluruhan terdiri dari bagian-bagian yang saling tergantung (interdependensi). Keseluruhan sistem yang utuh menentukan bagian-bagian. Artinya, bagian yang satu 
tidak dapat dipahami secara parsial dan terpisah kecuali dengan mempertahankan hubungan dengan sistem keseluruhan yang luas, dimana bagian-bagian menjadi unsurnya. Bagian-bagian harus dipahami dalam relevansinya dengan fungsi terhadap keseimbangan sistem keseluruhan, sehingga bagian-bagian tersebut menunjukan gejala saling tergantung dan saling mendukung untuk memelihara keutuhan sistem. Keempat, tiap-tiap masyarakat merupakan struktur yang terdiri dari unsur-unsur yang relatif kuat untuk berintegrasi satu sama lain dengan baik. Orang lebih banyak bekerjasama daripada menentang, biarpun telah terjadi pergantian dan perubahan-perubahan apapun (19).

Selanjutnya jika dilihat dari teori kerukunan sosial memandang keselarasan hubungan sosial dapat terjadi dalam interaksi antar elemen masyarakat dan kulturnya dengan setidaknya lima teori dasar. Pertama, Teori Nilai: kerukunan dan integrasi sosial dapat terjadi apabila masing-masing kelompok dan subkultur dalam masyarakat saling mentaati tatanan nilai-nilai sosial budaya. Kedua, Teori Struktural: kerukunan sosial dipengaruhi oleh struktur sosial dalam masyarakat. Pihak penguasa sebagai struktur tertinggi dapat menerapkan peraturanperaturan yang mengintegrasikan masyarakat. Ketiga, Teori Idealis: kerukunan sosial dapat terjalin apabila terdapat ide, gagasan, visi ataupun ideologi yang mengikat anggota masyarakat secara keseluruhan. Kelima, Teori Resiprositas: kerukunan sosial dan integrasi sosial dapat terjadi apabila dalam masyarakat dibangun jalinan sosial yang baik. Kelima, Teori interaksi: kerukunan sosial dapat terjadi apabila terjadi interaksi rasional antar kelompok, etnis, agama dan lain-lain dalam masyarakat yang saling menguntungkan dan memberikan manfaat (20).

Kerukunan merupakan kepentingan bersama yang tidak dapat dijauhkan dari perbedaan. Kerukunan umat beragama menjadi salah satu poin yang penting dalam kehidupan sosial yang harus ditopang minimal oleh dua hal, yaitu sikap kultural yang positif terhadap kemajemukan, dan kondisi struktural yang mendukung sikap positif tersebut. Sikap yang dimaksud terdiri dari toleransi, sikap saling menerima dan bekerjasama. Sehingga perbedaan bukan merupakan hambatan untuk menjalin kehidupan yang rukun berdampingan dalam bingkai persaudaraan dan persatuan (10).

Jika dilihat dari perspektif suku yang ada di kelurahan Pager, menurut informasi dari beberapa sumber dan hasil observasi penulis, maka dari jumlah 643 jiwa penduduk, mayoritas masyarakat adalah suku Dayak (sekitar 65\%), Suku Jawa (sekitar 30\%), suku Banjar (sekitar 7\%) sisanya Suku Sunda dan Suku Lainnya (3\%). Memahami keberadaan suku jika di kaitkan dengan kerukunan yang tercipta, maka nampaknya karakter kesukuan memiliki andil yang cukup besar dalam penciptaan keharmonisan dan kerukunan. Pada suku Dayak misalnya, menurut beberapa hasil riset, mereka memiliki karakter sangat toleran, terbuka dan mudah berinteraksi dengan siapapun bahkan dikalangan masyarakat Dayak muslim dan non muslim sering dijumpai mereka saling mengangkat saudara satu sama lain.

Faktor yang mendorong kerukunan dan keharmonisan atau ketidakrukunan dan ketidakharmonisan dalam masyarakat Ridwan Lubis dalam bukunya Cetak Biru Peran Agama menyebutkan bahwa ada 4 (empat) faktor yang mendorong kerukunan dan keharmonisan yakni: Pertama, pembentukan Organisasi Lintas Agama. Kedua, kearifan lokal masyarakat. Ketiga, aspek hukum atau regulasi yang mengarah pada kerukunan. Keempat, aspek historis, yang secara historis dapat diketahui bahwa masuknya agamaagama besar ke Indonesai umumnya tanah Jawa adanya suatu cara damai, tanpa paksaan dan kekerasan, tanpa senjata dan peperangan. Sedangkan faktor pendorong ketidakrukunan adalah: Pertama, pemahaman keagamaan, dimana setiap agama meyakini bahwa agamanya lah yang paling benar. Kedua, kesenjangan Ekonomi, pembangunan yang hanya mengutamakan pihak-pihak atau kelompok masyarakat tertentu dengan mengabaikan kelompok masyarakat lainnya, Ketiga, kepentingan politik. Keempat, persaingan antar ras dan suku, Kelima, Perbedaan Nilai Sosial Budaya (9).

Melihat relevansi antara pandangan Ridwan Lubis dengan realitas sosialnya menunjukkan kemiripan meskipun dilapangan ditemukan juga faktor lain, yakni faktor pemahaman keagamaan, faktor 
hubungan kekerabatan, faktor humanistik dan faktor sikap nasionalis. Teori tentang ketidakrukunan karena faktor persaingan antar ras dan suku, penduduk asli dan pendatang, perbedaan nilai sosial budaya juga tidak tampak pada masyarakat kelurahan Pager, meskipun tetap diakui dalam kaitan dengan pilihan politik saat pilkada tidak dapat dinafikan terasa ada, akan tetapi hanya sebatas lokal yakni pada pengurus/pendukung partai dan tidak berlangsung lama, artinya pasca pilkada, gesekan itu kembali normal seperti sediakala.

Konteks sikap keagamaan masyarakat, pluralisme merupakan salah satu dari tiga bagian tipologi keagamaan dalam perspektif teologis, di samping inklusivisme dan eksklusivisme. Seorang penganut agama yang bersifat inklusif, menilai bahwa keselamatan bukan monopoli agamanya. Penganut agama lain, yang secara implisit berbuat kebenaran menurut agamanya, juga dipandang akan memperoleh keselamatan. Pemeluk agama yang bersifat eksklusif, menilai bahwa agamanyalah yang benar sedangkan agama lain adalah salah dan sesat. Adapun penganut agama yang bersifat pluralis, menilai bahwa semua agama sama dan benar. Oleh karena itu, seseorang yang bersifat pluralis beranggapan bahwa tidak seharusnya umat beragama bersikap eksklusif dengan serangkaian klaim keselamatan dan kebenaran yang ditujukan khusus bagi pemeluknya (16).

Mengancu pada teori di atas dan mencermati pandangan keagamaan masyarakat di Kelurahan Pager dalam melihat agama lain, tampaknya dapat disimpulkan cenderung pada tipologi keagamaan yang pluralis. Masyarakat yang memiliki pandangan demikian rata-rata terdiri dari penganut agama Nasrani dan Hindu Kaharingan. Mereka memandang bahwa pada dasarnya semua agama adalah sama, yang membedakan hanya simbol keagamaan, tata cara ibadah dan tempat ibadah yang berbeda. Paham pluralisme, memandang bahwa nilai kebenaran dalam berbagai hal (agama, filsafat, hukum dll) adalah bervariatif dan tidak bersifat tunggal. Semua agama menawarkan kebenaran oleh sebab itu memeluk agama apapun dianggap benar, tidak ada agama yang paling mutlak benar. Agama manapun pasti mengantarkan orang pada keselamatan. Yang perlu ditegaskan adalah bahwa pluralisme bukan merupakan sinkretisme dan relativisme absolut. Sebab, pluralisme bukan berarti meniadakan adanya kebenaran dan persamaan yang global. Dalam setiap perbedaan, jelas ada persamaan dan kesatuan. Persamaan itulah yang terdapat dalam sikap kemanusiaannya (1).

Sedangkan masyarakat yang beragama Islam memiliki pandangan inklusivisme, yaitu suatu faham yang berpendapat bahwa kebenaran adalah apa yang disampaikan oleh doktrin agamanya, dengan tidak menutup kemungkinan doktrin agama lain juga membawa kebenaran. Kebenaran dalam agama sendiri harus diyakini sepenuh hati, sedang kebenaran dalam agama lain adalah untuk di hormati. Sepanjang hasil wawancara, tidak ditemukan masyarakat yang memiliki sikap keagamaan yang eksklusif yakni suatu faham atau doktrin yang mengajarkan bahwa kebenaran itu hanya milik salah satu agama, golongan, kelompok dan aliran tertentu.

Berkaitan dengan peran yang dimainkan elit atau tokoh agama maupun tokoh adat masyarakat Pager yang memposisikan diri sebagai pigur teladan dalam interaksi sosialnya yang penuh persahabatan dan persaudaraan yang ditandai saling mengundang dan mengunjungi serta saling membantu merupakan salah satu identitas masyarakat dalam membina dan menjaga kerukunan umat beragama. Peran seperti itulah yang harus dimainkan para elit agama. Hal ini tampaknya sejalan dengan pandangan Imam Tholkhah yang menyebukan bahwa sebagai elit agama, maka ada beberapa peran yang dapat dimainkan: Pertama, membangun interaksi sosial dengan masyarakat sekitar yang menunjukan adanya persaudaraan, persahabatan dan keramahan. Kedua, kesedian untuk tolong menolong tanpa membedakan suku dan agama, usia maupun jenis kelamin, kapanpun masyarakat memerlukannya. Ketiga, kesediaan untuk menjadi tempat bertanya, tempat mencari informasi tentang berbagai hal khususnya terkait dengan kehidupan keagamaan masyarakat. Keempat, menunjukkan prilaku yang patut diteladani, taat melakukan ibadah dan berakhlak mulia.

Demikian juga dalam perannya sebagai mubaligh, khotib, penceramah, pendeta atau 
sejenisnya, di dalam pemberian nasihat kepada pemeluk agama, sepatutnya memperhatikan beberapa hal, yakni: Perama, materi keagaman yang disampaikan hendaknya mengandung pesan moral yang ditujukan agar umat menyebarkan kasih sayang terhadap sesama manusia termasuk mereka yang berbeda keyakinan agama; Kedua, materi yang disampaikan hendaknya bukan sesuatu yang diduga dapat menimbulkan kebencian masyarakat terhadap penganut agama lain; Ketiga, kegiatankegiatan ritual maupun sosial keagamaan hendaknya tidak mengganggu ketentraman maupun kenyamanan penganut agama lain (18).

\section{Kesimpulan}

Aktualisasi dari kerukunan masyarakat beda agama di kelurahan Pager kecamatan Rakumpit Kota Palangka Raya diwujudkan dalam bentuk saling mengundang dan mengunjungi pada saat perayaan hari besar keagamaan, kegiatan kematian, perkawinan dan hajatan. Saling memberi bantuan baik pikiran maupun dalam bentuk finansial jika ada salah satu warga yang mengalami kesusahan atau mendirikan rumah ibadah, memberikan hadiah, menyiapkan makanan secara khusus bagi mereka yang berbeda agama. Membagi daging hewan kurban sebagai wujud berbagi kebahagiaan kepada warga muslim juga warga non muslim tanpa memandang agama, saling menghormati dan memberikan kebebasan dalam menjalankan ibadah meskipun dalam keluarga tersebut terdapat keluarga beda agama, saling menjaga dalam kegiatan dakwah dengan tidak menyudutkan agama lain dan tidak melakukan hal-hal yang dapat menimbulkan konflik antar agama serta melalui kegiatan gotong royong dan kerja bakti.

Tumbuhnya kesadaran membangun kerukunan melalui sikap keseharian sebagaimana disebutkan di atas didorong oleh beberapa faktor seperti faktor teologis (ajaran Tuhan yang terdapat didalam masing-masing kitab suci agama untuk membangun ukhuwah dan saling menyayangi), pemahaman keagamaan yang memandang bahwa pada dasarnya semua agama adalah sama dan yang membedakan hanya terminologi yang digunakan masing-masing agama serta tata cara ibadah dan tempat ibadah. Faktor lain adanya dorongan nilai-nilai filosofis dan kearifan budaya lokal yang dicontohkan dan dibangun oleh para leluhur seperti "Belom Bahadat", Hapakat Basara (permufakatan bersama), filosofi Rumah Betang yang mengajarkan makna hidup harmonis dan kebersamaan. Nilai-nilai humanistik dan emosional (memandang manusia pada dasarnya sama saja dari keturunan yang sama yakni anak cucu adam, hubungan kekerabatan (realitas masyarakat memiliki ikatan kekerabatan yang kuat satu sama lain) dan faktor emosional (perasaan tidak nyaman jika tidak baik dan terjadi konflik dengan sesama warga) serta nilai-nilai patriotis (kepahlawanan) dan nasionalis (cinta tanah air).

Terciptanya kerukunan dan keharmonisan antar warga di kelurahan Pager tidak lepas dari keterlibatan para tokoh agama, tokoh adat masing-masing agama, ketua RT/RW. Sementara peran pemerintah mulai dari pemerinah Kota, Kecamatan dan Kelurahan secara nyata dinilai masih kurang maksimal. Kehadiran FKUB sebagai organisasi yang diharapkan membina menjembatani hubungan internal maupun antar agama.

\section{Daftar Pustaka}

1. Erawati D. Peranan Sosialisasi Nilai Kebersamaan Dalam Upaya Menanggulangi Konflik Beragama Dalam Kehidupan Bermasyarakat di Kota Palangka Raya. Palita J Soc-Relig Res 2: 1-12, 2017.

2. Ghazali AM. Teologi Kerukunan Beragama dalam Islam (Studi Kasus Kerukunan Beragama di Indonesia). Anal J Studi Keislam 13: 271-292, 2017.

3. Hakis H. Komunikasi Antar Umat Beragama di Kota Ambon. J Komun Islam 5: 98-113, 2015.

4. Hamidi. Metode Penelitian Kualitatif. Malang: UMM Press, 2004.

5. Hendropuspito. Sosiologi Agama. Yogyakarta: Kanisius, 1983.

6. Ida I. Wawancara. 2017.

7. Jumiati. Wawancara. 2017.

8. Kartiman. Wawancara. 2017. 
9. Lubis MR, Barizi A. Cetak biru peran agama: merajut kerukunan, kesetaraan gender, dan demokratisasi dalam masyarakat multikultural. Departemen Agama, Badan Litbang Agama dan Diklat Keagamaan, Puslitbang Kehidupan Beragama, 2005.

10. Maretha NKW. Kontruksi Kerukunan Antar Umat Beragama Berbasis Ikatan Kekerabatan Polong Renten di Kecamatan Pemenang Kabupaten Lombok Utara. GaneC Swara 9: 96-100, 2015.

11. Mudzhar MA. Konflik Etno Religius Indonesia Kontemporer. Jakarta: Badan Litbang Agama dan Diklat Keagamaan, 2003.

12. Nasikhun. Sistem Sosial Indonesia. Jakarta: Rajawali Press, 1995.

13. Nazmudin. Kerukunan dan Toleransi Antar Umat Beragama dalam Membangun Keutuhan Negara Kesatuan Republik Indonesia (NKRI). J Gov Civ Soc 1: 23-39, 2018.

14. Nottingham E. Agama dan Masyarakat. Jakarta: Rajawali Press, 1996.
15. Sisi. Wawancara. 2017.

16. Sumbulah U, Nurjanah N. Pluralisme agama: Makna dan lokalitas pola kerukunan antarumat beragama. Malang: UIN Maliki Press, 2013.

17. Suryana T. Konsep dan Aktualisasi Kerukunan Antar Umat Beragama. J Pendidik Agama Islam 9: 127-136, 2011.

18. Tholkhah I. Membangun Kualitas Kerukunan Umat Beragama. Harmoni 3: 63-68, 2004.

19. Usman R. Konflik dalam Perspektif Komunikasi: Suatu Tinjauan Teoretis. Mediat J Komun 2: 31-41, 2001.

20. Widjaya. Penerapan Nilai-Nilai Pancasila dan Hak Asasi Manusia di Indonesia. Jakarta: PT Rineka Cipta, 2000. 